20 Hoffmann-Sommergruber, K., O'Riordain, G., Ahorn, H., Ebner, C., Laimer Da Camara, M. M., Puhringer, H., Scheiner, O. and Breiteneder, H. (1999) Clin. Exp. Allergy 29, 840-847

21 Son, D. Y., Scheurer, S., Hoffmann, A., Haustein, D. and Vieths, S. (1999) Eur. J. Nutr. 38, 20I-2I5

22 Karamloo, F., Scheurer, S., Wangorsch, A., May, S., Haustein, D. and Vieths, S. (200I) J. Chromatogr. B Biomed. Sci. Appl. 756, 28I-293

23 Hoffmann-Sommergruber, K., Ferris, R., Pec, M., Radauer, C., O'Riordain, G., Laimer Da Camara, M. M., Scheiner, O. and Breiteneder, H. (2000) Int. Arch. Allergy Immunol. 122, I15-123

24 Hoffmann-Sommergruber, K., Vanek-Krebitz, M., Ferris, R., O'Riordain, G., Susani, M., Hirschwehr, R., Ebner, C., Ahorn, H., Kraft, D., Scheiner, O. and Breiteneder, $\mathrm{H}$. (1996) Adv. Exp. Med. Biol. 409, 219-224

25 Breiteneder, H., Hoffmann-Sommergruber, K., O'Riordain, G., Susani, M., Ahorn, H., Ebner, C., Kraft, D. and Scheiner, O. (1995) Eur. J. Biochem. 233, 484-489

26 van Ree, R., Antonicelli, L., Akkerdaas, J. H., Pajno, G. B., Barberio, G., Corbetta, L., Ferro, G., Zambito, M., Garritani, M. S., Aalberse, R. C. and Bonifazi, F. (1996) Allergy 5I, 387-393

27 Moneo, I., Gomez, M., Sanchez-Monge, R., Alday, E., de las Heras, M., Esteban, I., Bootello, A. and Salcedo, G. (1999) Ann. Allergy Asthma Immunol. 83, 7I-75

28 Pyee, J., Yu, H. and Kolattukudy, P. E. (1994)

Arch. Biochem. Biophys. 311, 460-468
29 Fernandez-Rivas, M. and Cuevas, M. (1999) Clin. Exp. Allergy 29, 1239-1247

30 Asero, R., Mistrello, G., Roncarolo, D., Amato, S. and van Ree, R. (200I) Allergy 56, 259-260

31 Lindorff-Larsen, K. and Winther, J. R. (200 I) FEBS Lett. 488, $145-148$

32 Pastorello, E. A., Farioli, L., Pravettoni, V., Ispano, M., Scibola, E., Trambaioli, C., Giuffrida, M. G., Ansaloni, R., Godovac-Zimmermann, J., Conti, A., et al. (2000) J. Allergy Clin. Immunol. 106, 744-75।

33 Asero, R., Mistrello, G., Roncarolo, D., Amato, S. and van Ree, R. (200I) Ann. Allergy Asthma Immunol. 87, 65-67

34 Garcia-Casado, G., Crespo, J. F., Rodriguez, J. and Salcedo, G. (200 I) J. Allergy Clin. Immunol. 108, 647-649

35 Bonadonna, P., Crivellaro, M., Dama, A., Senna, G. E., Mistrello, G. and Passalacqua, G. (1999) J. Invest. Allergol. Clin. Immunol. 9, 268-270

36 Figueredo, E., Quirce, S., del Amo, A., Cuesta, J., Arrieta, I., Lahoz, C. and Sastre, J. (1999) Allergy 54, 630-634

37 Fernandez-Anaya, S., Crespo, J. F., Rodriguez, J. R., Daroca, P., Carmona, E., Herraez, L. and Lopez-Rubio, A. (1999) J. Allergy Clin. Immunol. 103, 959-960

38 Curioni, A., Santucci, B., Cristaudo, A., Canistraci, C., Pietravalle, M., Simonato, B. and Giannattasio, M. (1999) Clin. Exp. Allergy 29, 407-4I3

Received 10 June 2002

\title{
Stability of recombinant $\mathbf{2} \mathbf{S}$ albumin allergens in vitro
}

\author{
G. J. Murtagh*1, M. Dumoulint, D. B. Archer* and M. J. Alcocer*
}

*School of Life and Environmental Sciences, University of Nottingham, University Park, Nottingham NG7 2RD, U.K., and †Department of Chemistry, University of Cambridge, Lensfield Road, Cambridge CB2 IEW, U.K.

\section{Abstract}

Two well known $2 \mathrm{~S}$ albumins, Ber e 1 from brazil nut and sunflower $2 \mathrm{~S}$ albumin 8 (SFA-8), have been expressed in a eukaryotic system and purified. Analysis of recombinant versions of Ber e 1 and SFA-8 revealed them to be significantly more resistant to digestion by pepsin than $\mathrm{BSA}$, and to be stable for up to $30 \mathrm{~min}$ in simulated gastric fluid. Unfolding monitored by CD indicated that both proteins were also very resistant to denaturation induced by heat and low $\mathrm{pH}$. These results suggest that, although the ability of $2 \mathrm{~S}$ albumins to reach the circulatory system may be a prerequisite for the allergenicity of this group

Key words: allergenicity, Ber e I, SFA-8, simulated gastric fluid, unfolding.

Abbreviations used: Ber e I and rBer e I, native and recombinant brazil nut $2 \mathrm{~S}$ albumin respectively; SFA-8 and rSFA-8, native and recombinant sunflower $2 \mathrm{~S}$ albumin 8 respectively; SGF, simulated gastric fluid.

ITo whom correspondence should be addressed (e-mail gareth.murtagh@nottingham.ac.uk). of proteins, stability is just one of a number of characteristics that provoke a selective immune response.

\section{Introduction}

In light of the growing number of genetically engineered crops and the observation that the horizontal transfer of allergens can occur unintentionally during transgenic studies [1], a decision tree has been recommended to ensure the safety of foods derived from biotechnology $[2,3]$. The stability of proteins, as measured by resistance to proteolysis by simulated gastric fluid (SGF), is an important factor in the assessment of the allergenicity of proteins [4]. Many allergens have been found to be consistently more resistant to digestion by pepsin than other proteins, and the ability of an intact protein to reach the circulatory system maybe a prerequisite for allergenicity [3]. $2 \mathrm{~S}$ seed albumins have been associated with both allergy, in the oil milling and baking industries [5], and the genetic enhancement of nutrient-poor crops [6]. 
Several proteins from this group, including Ber e 1 from brazil nut, have been characterized as clinically important allergens [7]. In contrast with Ber e 1, and despite a high level of consumption, allergy to sunflower $2 \mathrm{~S}$ albumin (SFA-8) is less well described [8,9]. Purification of allergens is often problematic, and the production of recombinant versions may enable standardization of allergens for mechanistic studies, diagnostics and antigen-based therapies [10].

\section{Materials and methods}

\section{Extraction and purification of native and recombinant proteins}

Recombinant Ber e 1 and SFA-8 (rBer e 1 and rSFA-8 respectively) were produced in the yeast Pichia pastoris and purified by FPLC using a heparin-Sepharose column [11]. BSA was obtained from Sigma.

\section{SGF digests}

SGF contained $0.32 \%(\mathrm{w} / \mathrm{v})$ pepsin (Sigma) in $30 \mathrm{mM} \mathrm{NaCl} / 0.7$ \% (v/v) HCl, pH 1.2 [12,13]. Digestions contained $120 \mu \mathrm{l}$ of SGF and $23 \mu \mathrm{g}$ of purified protein. Incubations were maintained at $37^{\circ} \mathrm{C}$ and samples were removed at each time point and quenched with $\mathrm{Na}_{2} \mathrm{CO}_{3}$ (final concentration $70 \mathrm{mM}$ ), before freezing until electrophoresis. Proteins were separated by discontinuous SDS/ PAGE under reducing conditions using the NuPAGE ${ }^{\circledR}$ Novex system (Invitrogen) as per the manufacturer's instructions.

\section{CD measurements}

Far-UV CD spectra for the analysis of unfolding induced by heat and acidic conditions were generated as described in [11]. Protein concentration was determined using a BCA protein assay kit (Pierce) and a concentration of $0.146 \mathrm{mg} \cdot \mathrm{ml}^{-1}$ (rBer e 1) or $0.318 \mathrm{mg} \cdot \mathrm{ml}^{-1}(\mathrm{rSFA}-8)$ in $10 \mathrm{mM}$ phosphate buffer, pH 6.8, or $0.1 \mathrm{M}$ glycine buffer, $\mathrm{pH} 2.2$, used in experiments.

\section{Results}

\section{Digestion in SGF}

In previous studies of plant-food allergens, native $2 \mathrm{~S}$ albumins were found to be among the proteins that are most stable to digestion by SGF [13]. In the current study, purified recombinant versions of the $2 \mathrm{~S}$ albumins Ber e 1 and SFA- 8 were also found to be resistant to hydrolysis by SGF. BSA, included as a non-plant albumin representative, was found to be very unstable in the presence of $\mathrm{SGF}$, with the $62 \mathrm{kDa}$ band disappearing after approx. 5 s. (Figure 1). Investigations of purified rBer e 1 revealed it to be stable to digestion in SGF for over $15 \mathrm{~min}$, with no fragments visible after 30 min. Experiments with rSFA-8 protein revealed a pattern of digestibility similar to that observed with rBer e 1, with bands and fragments persisting for up to $30 \mathrm{~min}$ after the addition of SGF (Figure 1).

\section{CD analysis}

The stability of $2 \mathrm{~S}$ albumins was further investigated by far-UV CD spectroscopy of rBer e 1 and rSFA-8 during heating and at low pH. At pH 6.8, the secondary structure of rBer e 1 was highly resistant to thermal unfolding (Figure 2A). Temperatures higher than $75^{\circ} \mathrm{C}$ were achieved before rBer e 1 started to unfold, while at $95^{\circ} \mathrm{C}$ these proteins still retained most of their secondary structure (results not shown). Spectra obtained at $\mathrm{pH} 2.2$ and $25^{\circ} \mathrm{C}$ were superimposable with those recorded at $\mathrm{pH} 6.8$, confirming that rBer e 1 was also highly resistant to acidic $\mathrm{pH}$ (Figures $2 \mathrm{~A}$ and 2B). When heated at $\mathrm{pH} 2.2$, rBer e 1 started to unfold at approx. $65^{\circ} \mathrm{C}$. At $95^{\circ} \mathrm{C}$, although the protein was significantly destabilized, the transition was not complete (results not shown). Upon cooling, the denaturation was largely reversible (Figure 2).

At temperatures up to $95^{\circ} \mathrm{C}$ at $\mathrm{pH} 6.8, \mathrm{rSFA}$ 8 also retained most of its native structure, similar to both rBer e 1 and the behaviour described for the corresponding plant protein [14]. rSFA-8 was slightly less resistant to unfolding induced by acidic $\mathrm{pH}$ than was rBer e 1 (results not shown).

\section{Discussion}

We have demonstrated that the recombinant $2 \mathrm{~S}$ albumins Ber e 1 and SFA-8 have considerable

\section{Figure I}

In vitro digestibility in SGF

C represents a sample without the addition of SGF.

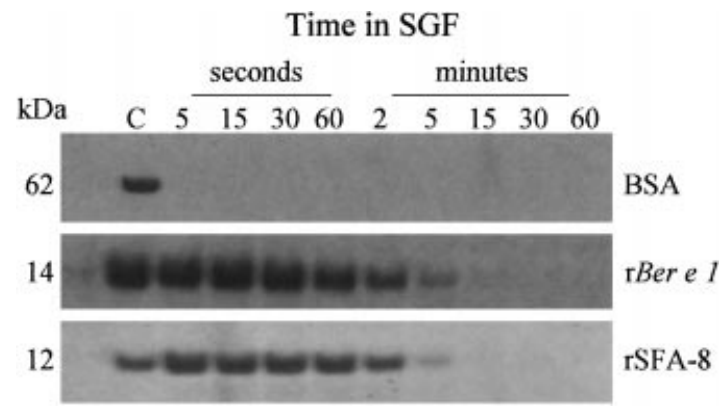




\section{Figure 2}

\section{CD spectra of Ber e I $\left(0.146 \mathrm{mg} \cdot \mathrm{ml}^{-1}\right)$ under various conditions}

Conditions were (A) $10 \mathrm{mM}$ phosphate buffer, $\mathrm{pH} 6.8$, and (B) $10 \mathrm{mM}$ glycine buffer, $\mathrm{pH}$ 2.2.

Temperatures: $25^{\circ} \mathrm{C}$ upon heating; $\boldsymbol{\Delta}, 95^{\circ} \mathrm{C} ; 0,25^{\circ} \mathrm{C}$ upon cooling.

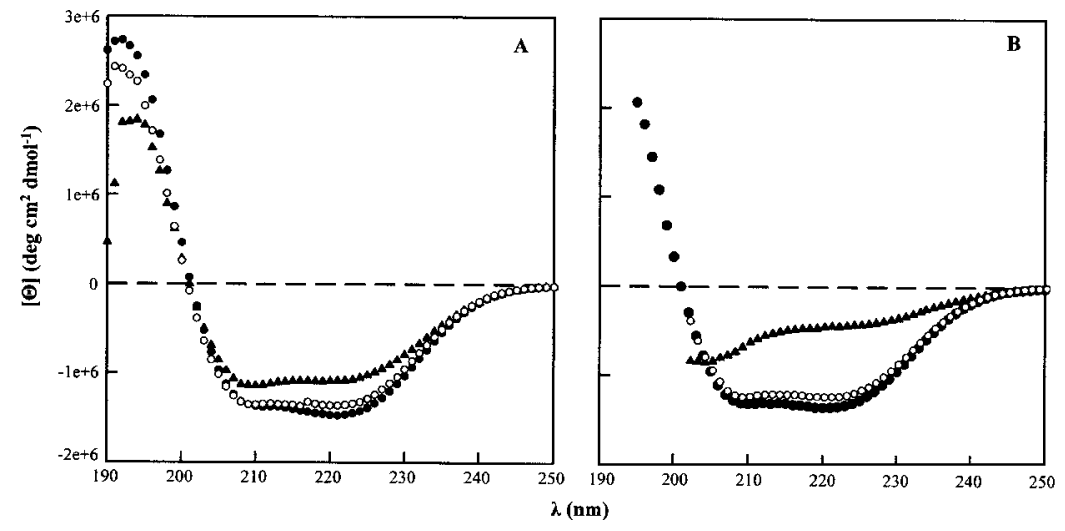

stability to hydrolysis by SGF, whereas BSA was hydrolysed after a few seconds. Further, this proteolytic stability was found to be reflected by a high resistance to unfolding induced by heat and acidity. As the $2 \mathrm{~S}$ albumins are non-glycosylated proteins, the high stability observed may be explained by their compact three-dimensional structure. Similar structural characteristics are shared by other members of the prolamin superfamily, which accounts for $35 \%$ of the allergenic or allergenic-like sequences currently known (www.sanger.ac.uk/software/pfam).

It is of considerable interest that allergenicity of SFA-8 has not been well described, despite common use and consumption. Although $\operatorname{IgE}$ binding to sunflower albumins has been observed, it is unclear whether or not SFA-8 is the major allergen [9], and reports of adverse reactions are very rare [8]. This may suggest that stability is only one of a number of characteristics that confer on proteins the ability to provoke selective immune responses.

\section{References}

I Nordlee, J. A., Taylor, S. L., Townsend, J. A., Thomas, L. A. and Bush, R. K. (1996) N. Engl. J. Med. 334, 688-692

2 FAOMHO (200I) Evaluation of Allergenicity of Genetically Modified Foods, Food and Agriculture Organisation of the United Nations (FAO), Rome, Italy
3 Metcalfe, D. D., Astwood, J. D., Townsend, R., Sampson, H. A., Taylor, S. L. and Fuchs, R. L. (1996) CRC Crit. Rev. Food Sci. 36, SI65-SI86

4 Huby, R. D. J., Dearman, R. J. and Kimber, I. (2000) Toxicol. Sci. 55, 235-246

5 Youle, R. J. and Huang, A. H. C. (198I) Am. J. Bot. 68, 44-48

6 Saalbach, I., Pickardt, T., Machemehl, F., Saalbach, G., Schieder, O. and Muntz, K. (1994) Mol. Gen. Genet. 242, 226-236

7 Pastorello, E. A., Farioli, L., Pravettoni, V., Ispano, M., Conti, A., Ansaloni, R., Rotondo, F., Incorvaia, C., Bengtsson, A., Rivolta, F., et al. (1998) J. Allergy Clin. Immunol. 102, 1021-1027

8 Axelsson, I. G. K., Ihre, E. and Zetterström, O. (1994) Allergy 49, 517-520

9 Kelly, J. D. and Hefle, S. L. (2000) Allergy 55, 556-559

10 Yasuhara, T., Takai, T., Yuuki, T., Okudaira, H. and Okumura, Y. (200 I) Clin. Exp. Allergy 3I, I I6-124

II Alcocer, M. J. C., Murtagh, G. J., Bailey, K., Dumoulin, M., Sarabia, A., Parker, M. J. and Archer, D. B. (2002) J. Mol. Biol., in the press

12 Roesler, K. R. and Rao, A. G. (200 I) J. Agric. Food Chem. 49, 3443-345I

13 Astwood, J. D., Leach, J. N. and Fuchs, R. L. (1996) Nat. Biotechnol. 14, 1269-1273

14 Pandya, M. J., Williams, P. B., Dempsey, C. E., Shewry, P. R. and Clarke, A. R. (1999) J. Biol. Chem. 274, 26828-26837

Received 18 July 2002 